\title{
Effectiveness of Monetary Policy Instruments on Economic Growth in Jordan Using Vector Error Correction Model
}

\author{
Rami Obeid $^{1} \&$ Bassam Awad ${ }^{2}$ \\ ${ }^{1}$ Head of Data Analysis \& Management Division, Central Bank of Jordan, Amman, Jordan \\ ${ }^{2}$ Head of Systemic Risk \& Macroprudential Policy Analysis Division, Central Bank of Jordan, Amman, Jordan, \\ Tel: 962 795-088-481. E-mail: bra05@my.fsu.edu \\ Correspondence: Rami Obeid, Central Bank of Jordan, PO Box 37, Amman, Jordan. Tel: 962-795-855-036. \\ E-mail: rami.obeid3@gmail.com
}

Received: September 13, 2017

Accepted: October 18, 2017

Online Published: October 25, 2017

doi:10.5539/ijef.v9n11p194

URL: https://doi.org/10.5539/ijef.v9n11p194

\begin{abstract}
The global financial crisis emphasized the important role of the prudent monetary policy in supporting economic growth through maintaining price stability. The monetary policy operational framework that was designed in 2008 was updated to include more instruments for managing monetary policy learning from the crisis lessons. Several studies analyzed various dimensions related to economic growth in Jordan such as Abdul-Khaliq, Soufan, and Abu Shihab (2013) and Assaf (2014), there were no studies that investigated the effect of monetary policy on economic growth in Jordan, at least recently, however. The study aims at measuring the effect of monetary policy instruments on the performance of Jordanian economy. Using quarterly data covering the period (2005-2015), an econometric model was examined using Vector Error Correction Model to assess the impact of monetary policy instruments on economic growth. The foremost advantage of VECM is that it has a nice interpretation of long-term and short-term equations. The results showed the existence of positive long-term and short-term effects of monetary policy instruments on the growth of real GDP. The model included three monetary policy instruments besides money supply. They are required reserve ratio, rediscount rate and overnight interbank loan rates as independent variables, and the real GDP growth as a dependent variable. The stationarity of the model time series was addressed. In addition, the stability of the model was tested using stability diagnostics tools. The results showed also an existence of inverse relationship between rediscount rate and economic growth in Jordan over both long and short terms.
\end{abstract}

Keywords: monetary policy instruments, vector error correction model, economic growth, money supply, Jordan

\section{Introduction}

Interest in monetary policy has been growing since the last century, as the importance of monetary policy lies in its role in maintaining monetary stability in countries, maintaining the stability of the general level of prices of goods and services, in addition to maintaining the stability of the local currency exchange rates. Furthermore, central banks use monetary policy instruments to influence the level of liquidity and structure of interest rates in the banking sector in line with the requirements of monetary and banking stability and thus support economic growth. Monetary policy is important because it plays a vital role in the economic system by addressing imbalances in the monetary system that adversely affect growth rates and production level, employment, real income and wealth distribution. Hence, central banks contributes to achieving the goal of maintaining monetary stability through their role of monetary policy management.

The Jordanian economy suffered from severe shocks during the period (2005-2015) because of the recent global financial crisis. Political and economic unrest in the Middle East adversely affected this small open oil importing emerging market economy country, this has shown the importance of monetary policy to achieve the economic and monetary stability by maintaining positive economic growth rates in the difficult circumstances surrounding the area. Therefore, the importance of research on the effectiveness of monetary policy tools to maintain positive economic growth rates has become evident.

Few studies investigated the variables affecting economic growth in Jordan in general and the monetary policy in particular. For example, Assaf (2014) investigated the relationship between some macroeconomic variables and economic growth of Jordan using multiple linear regression and found that exports and inflation has a positive 
impact on growth. While there was no statistically significant impact of foreign direct investment in economic growth (Assaf, 2014).

Abdul-Khaliq, Soufan, and Abu Shihab (2013) used descriptive statistical analysis to examine the coribution of production factors to economic growth. And found that “... the rate of economic growth depends on the intensive growth which reflects on intangible aspects that does not reflect changes visible in the accumulation of factors of production rather than the expanded growth through increasing the capital and labor."(Abdul-Khaliq, Soufan, \& Abu Shihab, 2013)

This study tries to pinpoint the role of monetary policy in achieving the desired levels of economic growth to come up with appropriate recommendations that might help policymakers assess the performance of monetary policy in Jordan.

This paper analyzes the effect of monetary policy on economic growth in Jordan through an examination of the impact of monetary policy instruments on GDP growth. The study problem can be formulated in the question: What is the impact of changing monetary policy instruments on economic growth in Jordan?

To answer this question, the paper tests the following four hypotheses:

1) There is no long and short-term relationship between the Required Reserve Ratio and economic growth in Jordan.

2) There is no long and short-term relationship between Money Supply (M1) and economic growth in Jordan.

3) There is no long and short-term relationship between Weighted Average Interest Rates on Interbank and economic growth in Jordan.

4) There is no long and short-term relationship between Re-Discount Rate and economic growth in Jordan.

\section{The Concept of Monetary Policy}

There are several definitions of monetary policy used by economists. These definitions varied in the economic literature. For example, According to Einsig (1954), "monetary policy includes all monetary decisions and measures irrespective of whether the aims are monetary or non-monetary, and all monetary decisions that aim at affecting the monetary system." (Einsig, 1954). Monetary policy is defined by Patat (1987) as "work which is used to control the money supply by the central bank as a tool to achieve the objectives of economic policy." (Patat, 1987).

The importance of monetary policy that aims to achieve the important objective of the economies is to maintain monetary and economic stability by maintaining stability of the general price level and the stability of the exchange rate of the local currency, monetary policy enhances the economic growth thus the economic development as well. In addition, monetary policy maintains the soundness of banks and contributes to achieving the desired balance of payments.

According to Glahe (1977), monetary policy relationship with economic growth and price level has been discussed with great interest by various schools of economic thought. The Keynesian school assumed that monetary policy affects income via interest rate tool and investment only, but a number of economists considered that it is a limited vision, for example, the pioneers of the New-Keynesian theory think that the changes in interest rates caused by changes in money supply in the market are the basis for monetary policy. According to this theory, the initial impact of monetary policy would be on the capital goods industry, and these changes result in changes in consumption and income through investment multiplier (Glahe, 1977).

As for the Monetary School, it believes that the change in money supply is most closely associated with monetary policy. Where the money supply depends essentially on the assumption that individuals desire to save a certain percentage of their income. Through monetary policy and its ability to change the level of individual savings. Individuals will try to return to the same level of the desired disposable income. Consequently, this might result in a change in the behavior of individuals directly at the level of aggregate demand and prices. Monetary policy affects directly not only investment expenditures as the New Keynesian theory claims but also total expenditures.

\section{Literature Review}

Several studies investigated the relationship between the monetary policy and the economic growth. Friedman \& Schwartz (1973) demonstrated that the change in money supply has a significant impact on the economy. Their work was based on an analysis of historical data for the United States, where they assumed that the growth of money supply has an impact on cash income and growth, Friedman and Schwartz noted a causal relationship 
between money supply and economic activity. They also noted that the money supply is rises at the economic boom periods and declines at the economic downturn. They also reached that the peak in the rate of money supply precedes the peak in the economic cycle. In addition, the minimum rate of monetary growth precedes the minimum of economic activity in the economic cycle. Friedman and Schwartz concluded that the change in money supply caused no change in economic activity, but the causal relationship is going from the money supply to economic activity, and that any substantial change to the rate of growth of the money supply would cause a substantial growth in the growth rate of cash income. In addition, they emphasized that the growth rate of the money supply for long periods will manifest itself in a different rate of price change (Friedman \& Schwartz, 1973).

The study of Chari et al. (1995) found that monetary policy contributes to determining inflation, where there is a negative relationship between inflation and the economic growth. The Increasing of the inflation rate by $15 \%$ leads to a decreased rate of economic growth between $0.2-0.7 \%$. In this study, they used the growth in money supply to measure the correlation between inflation and economic growth, with the aim of comparing monetary policies between countries (Chari, Jones, \& Manuelli, 1995).

The study of Levine and Renelt (1992) concluded that countries that have achieved faster growth rates are the countries that have had an annual inflation rate of $12.34 \%$ per year, While those countries that grew more slowly had $31.13 \%$ annual inflation rate (Levine \& Renelt, 1992).

Easterly, King, Levine, and Rebelo (1994) found similar results, where the countries with the fastest growth, 4\%, had an annual inflation rate of $8.42 \%$, and countries with slow growth had $16.50 \%$ inflation rate. The study found that countries with the fastest growth had high investment ratios of GDP and low market interest rates, and the study showed that the relationship between inflation and growth explained that the differences in monetary policies are important determinants in economic growth performance (Easterly, King, Levine, \& Rebelo, 1994).

Basu (2001) argued in his study that required reserve ratio could accelerate economic growth through public spending (Basu, 2001).

Balogun (2007) used Generalized Least Square (GLS) method to explore the relationship between monetary policy and economic growth in West African countries using money supply, rediscount rate, credit to private and government sectors and exchange rate. He showed that monetary policy was a source of stagnation as it hurt real domestic output of these countries (Balogun, 2007).

The study of Nouri and Samimi (2011) examined the impact of money supply as a measure of monetary policy on the Iranian economy growth using OLS, the results shows a significance and positive relationship between Money supply and economic growth in Iran (Nouri \& Samimi, 2011).

Fasanya and Onakoya (2013) used VECM to measure the impact of monetary policy on economic growth in Nigeria. The results showed the existence of long-term relationship among the variables, also the study shows that the inflation rate, exchange rate and external reserve are significant monetary policy tools that drive economic growth in Nigeria (Fasanya \& Onakoya, 2013).

Precious and Palesa (2014) used a VECM model to explore the role played by monetary policy tools in influencing economic growth in in the South African economy, the study showed that money supply, exchange rate and REPO rate are insignificant monetary policy tools that drive economic growth in South Africa whilst inflation is significant (Precious \& Palesa, 2014).

Lacker (2014) showed that the impact of monetary policy on the real economy is limited. This can be explained by the IS-LM model. For example, if central banks use expansionary monetary policy by open market operations lead to right ward shift in LM curve, this mean that interest rate decreases and the GDP goes up. However, these consequences are considered as a temporary short-run effect of monetary policy. Then the price level would increase (Lacker, 2014).

Algahtani (2015) found in his study that an increase of $1 \%$ of the Saudi Interbank Offered Rate (SIBOR) leads to decline in the GDP in quarter 2 and quarter 3 by $-0.090 \%$ and $-0.095 \%$ respectively in the Saudi Economy (Algahtani, 2015).

Whereas this paper focuses on interest rate as a monetary transmission channel, there are of course other transmission mechanisms of monetary policy than the interest rate channel. Mishkin (1996) discussed various monetary policy transmission channels, including interest rate channel, the channels operating through other asset prices and credit channels (Mishkin, 1996). Other than interest rate channels, the discussion of these channels is, however, beyond the scope of this paper. Regarding the interest rate channel, Taylor (1995), through surveying the literature on interest rate channels, found a strong empirical evidence of interest rate channels 
through affecting consumption and investment (Taylor, 1995).

\section{The Evolution of Monetary Policy and Its Operational Framework in Jordan (2005-2015)}

\subsection{The Traditional Monetary Policy Instruments}

The Central Bank of Jordan (CBJ) modified these instruments several times during the study period in light of many developments in the Jordanian economy and according to the level of foreign exchange reserves, current account deficit and inflation. In addition, it has created a conducive environment to stimulate economic growth and provided the required credit cost suitable for various economic activities.

Table 1 illustrates the most prominent developments in five instruments, or tools, of monetary policy. They are rediscount rate, overnight repurchase agreements rate (repo), overnight deposit window rate, required reserve ratio and overnight interbank lending rate.

Discount rate is the interest rate at which the central banks charge commercial banks for short-term loans. Repo rate is the rate at which the central bank lends short-term money to the banks against securities. Overnight deposit window rate is an instrument of monetary policy that is controlled by central banks that allows eligible institutions to borrow money from the central bank, usually on a short-term basis, to meet temporary shortages of liquidity caused by internal or external disruptions. Required reserve ratio is the fraction of deposits that central bank require a bank to hold in reserves and not lend out. If the required reserve ratio is 0.1 , this means that a bank must hold $10.0 \%$ of each JD it has in deposit in reserves, but can lend out $90.0 \%$ of this JD. Overnight weighted average interest rates on interbank loans, or simply interbank lending rate is the rate of interest charged on short-term loans made between banks.

As seen from Table 1, the rediscount rate has been declining since 2006 (except in 2012). This rate declined from $7.50 \%$ at the end of 2006 to $3.75 \%$ the end of 2015 . With respect to the overnight repurchase agreement rate, it was $7.50 \%$ and $8.5 \%$ at the end of 2005 and 2006 respectively, and decreased gradually until the end of 2010 to $4.00 \%$ before returning to rise by the end of 2012 to reach $4.75 \%$. However, the rate resumed its downward trend after the year 2012 to reach $3.5 \%$ at the end of 2015; the lowest price during the period (2005-2015). The relatively low rediscount and repos rates that characterized the period from 2012 until the end of the study period are attributed to several reasons. Most notably providing appropriate investment environment and stimulating economic activity after growth of foreign reserves and the relative decline in inflationary pressures, in addition to reducing the cost of borrowing for the public and private sectors that reflected positively on the aggregate demand.

As for the overnight deposit window rate, its highest value was 5.25\% at the end of 2006. However, it declined afterwards to settle at $2.00 \%$ at the end of 2010. It then resumed its upward trend in the next two years to reach $4.00 \%$ at the end of 2012. This increase is attributed to several reasons, most notably the increase in the attractiveness of financial instruments, liberated Jordanian Dinar, the enhanced national savings and curbing any possible future inflationary pressures. In addition to sending messages to investors and bank customers about the attractiveness of the JD. It is worth mentioning that other tools were used in the same period in order to provide the required credit for economic activities at reasonable costs (interest rates). However, after 2012, the overnight deposit window rate dropped to $1.50 \%$ by the end of 2015 - the lowest in the study period. The required reserve ratio amounted to $8.00 \%$ during the period (2005-2007) and then rose in 2008 to reach the peak of $9.00 \%$ before declining to $7.00 \%$ that prevailed for the whole remaining study period.

Table 1. Prices of monetary policy tools (2005-2015) (\%)

\begin{tabular}{cccccc}
\hline Year & $\begin{array}{c}\text { Required Reserve Ratio on } \\
\text { Banks' Deposits }\end{array}$ & $\begin{array}{c}\text { Overnight Weighted Average Interest } \\
\text { Rates on Interbank Loans }\end{array}$ & $\begin{array}{c}\text { Overnight Deposit } \\
\text { Window Rate }\end{array}$ & $\begin{array}{c}\text { Interest Rate on } \\
\text { Repurchase Agreements }\end{array}$ & $\begin{array}{c}\text { Rediscount } \\
\text { Rate }\end{array}$ \\
\hline 2005 & 8.00 & 4.60 & 4.50 & 7.50 & 6.50 \\
2006 & 8.00 & 6.50 & 5.25 & 8.50 & 7.50 \\
2007 & 8.00 & 5.20 & 4.75 & 6.75 & 7.00 \\
2008 & 9.00 & 4.70 & 4.00 & 6.00 & 6.25 \\
2009 & 7.00 & 2.70 & 2.50 & 4.50 & 4.75 \\
2010 & 7.00 & 2.20 & 2.00 & 4.00 & 4.25 \\
2011 & 7.00 & 2.90 & 2.25 & 4.25 & 4.50 \\
2012 & 7.00 & 4.30 & 4.00 & 4.75 & 5.00 \\
2013 & 7.00 & 3.80 & 3.50 & 4.25 & 4.50 \\
2014 & 7.00 & 2.90 & 2.75 & 4.00 & 4.25 \\
2015 & 7.00 & 2.00 & 1.50 & 3.50 & 3.75 \\
\hline
\end{tabular}

Source: (Central Bank of Jordan, Statistical Database, 2017). 


\subsection{Money Supply}

M1 amounted to about 9.9 JD billion in 2015 compared to 4.1 JD billion in 2005. While M2 approximated 31.6 JD billion at the end of 2015 compared to 12.4 JD billions in 2005 (Table 2).

Regarding the change in the money supply M1 and M2 during the study period, the rate of change of M1 amounted to $11.0 \%$. While the rate of change of M2 amounted 10.5\%, the largest change in M1 amounted to $27.2 \%$ in 2005, while the largest change in M2 approximated $17.3 \%$ in 2008 (Figure 1). It should be noted that the shrinkage in M1 at the end of 2012 relative to 2011 was a result of the decline in demand deposits in JD from 4,252.2 JD million to 3,996.1 JD million.

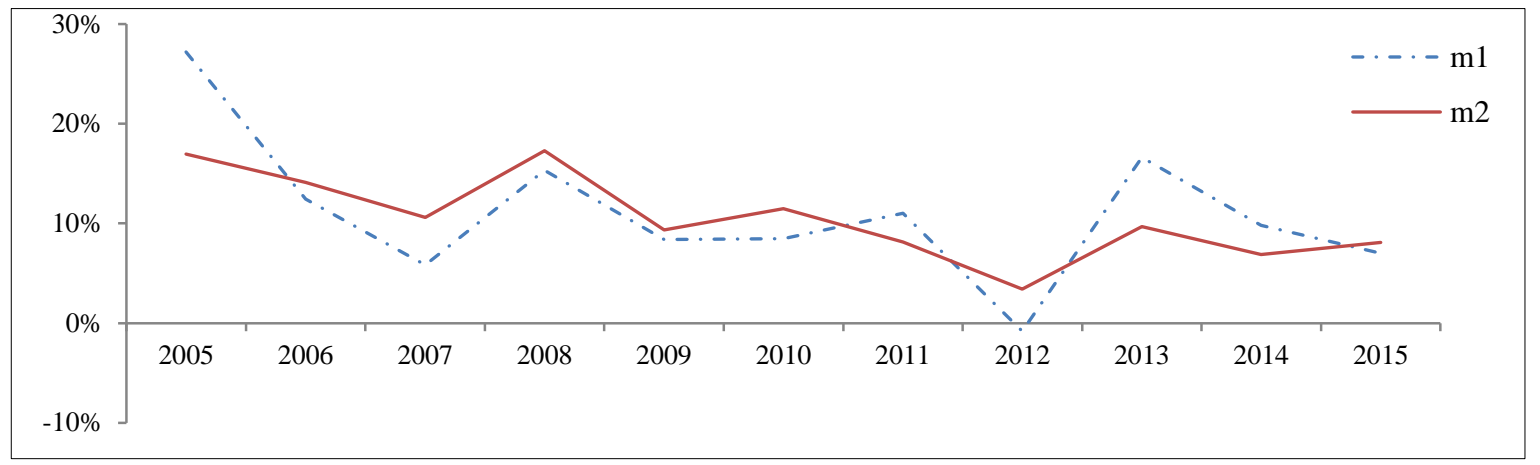

Figure 1. M1 and M2 (2005-2015) (y-o-y, \%)

Table 1. M1 and M2 (2005-2015)

\begin{tabular}{|c|c|c|c|c|}
\hline \multirow[b]{2}{*}{ Year } & \multirow[b]{2}{*}{ JD Million } & \multirow{2}{*}{$\begin{array}{c}\text { M1 } \\
\%\end{array}$} & \multicolumn{2}{|c|}{ M2 } \\
\hline & & & JD Million & $\%$ \\
\hline 2005 & $4,061.3$ & & $12,364.0$ & \\
\hline 2006 & $4,566.5$ & 12.4 & $14,109.7$ & 14.1 \\
\hline 2007 & $4,833.1$ & 5.8 & $15,606.8$ & 10.6 \\
\hline 2008 & $5,573.0$ & 15.3 & $18,304.2$ & 17.3 \\
\hline 2009 & $6,039.5$ & 8.4 & $20,013.3$ & 9.3 \\
\hline 2010 & $6,550.0$ & 8.5 & $22,306.7$ & 11.5 \\
\hline 2011 & $7,271.5$ & 11.0 & $24,118.9$ & 8.1 \\
\hline 2012 & $7,211.1$ & -0.8 & $24,945.1$ & 3.4 \\
\hline 2013 & $8,408.4$ & 16.6 & $27,363.4$ & 9.7 \\
\hline 2014 & $9,231.7$ & 9.8 & $29,240.4$ & 6.9 \\
\hline 2015 & $9,880.2$ & 7.0 & $31,605.5$ & 8.1 \\
\hline
\end{tabular}

\subsection{Developing the Monetary Policy Operational Framework}

The CBJ continued to implement monetary policy to achieve monetary and financial stability in the Kingdom, by continuing to follow economic conditions and various relevant variables and then using all the tools available at the appropriate time for achieving those goals. These tools are divided into main interest rates and open market operations. Within the context of the CBJ's strategy of continuous development of its monetary policy tools to achieve its objectives in line with the economic and monetary conditions, it has established an operational framework of monetary policy and its tools to determine their effectiveness in achieving the objectives of monetary policy.

Because of the aforementioned revision, since 2012, the CBJ continuously review and update the monetary policy operational framework and its tools. The most recent update granted the commercial banks more flexibility in managing liquidity in line with financial and monetary conditions under the high volume of financing needs for Jordan. This has resulted in updating the operational framework for the new monetary policy tools discussed next.

\subsubsection{Temporary Open Market Operations}

These operations are designed to enhance open-market operations to influence the size of the excess reserves and 
adjusting overnight interbank rates within the Corridor System and targeting market interest rates at the desired level of monetary policy, by introducing the securities repurchase agreements for a week to a month through auctions conducted by the Central Bank.

\subsubsection{Outright Open market Operations}

This tool provided the CBJ of the ability to access the money market as a seller and buyer of Government securities and guaranteed pump or withdrawal liquidity in accordance with the requirements of economic activity, and to enhance the role of the secondary market dealing in bonds.

\subsubsection{Currency Swap}

According to this tool, the CBJ made several foreign currency swaps in Jordanian dinars in response to requests by licensed banks to strengthen the dinar liquidity banks

\subsubsection{Corridor System}

Where this system is used in the implementation of monetary policy, price adjustment aims to influence on overnight interbank interest rate, which in turn affects interest rates in the market. The overnight deposit interest rate represents the floor of the system while the repurchase agreement interest rate represents the ceiling of the system.

Figure 2 illustrates the principle of Corridor system, as seen from the figure that the overnight interbank interest rate moving between the overnight deposit interest rate and REPO.

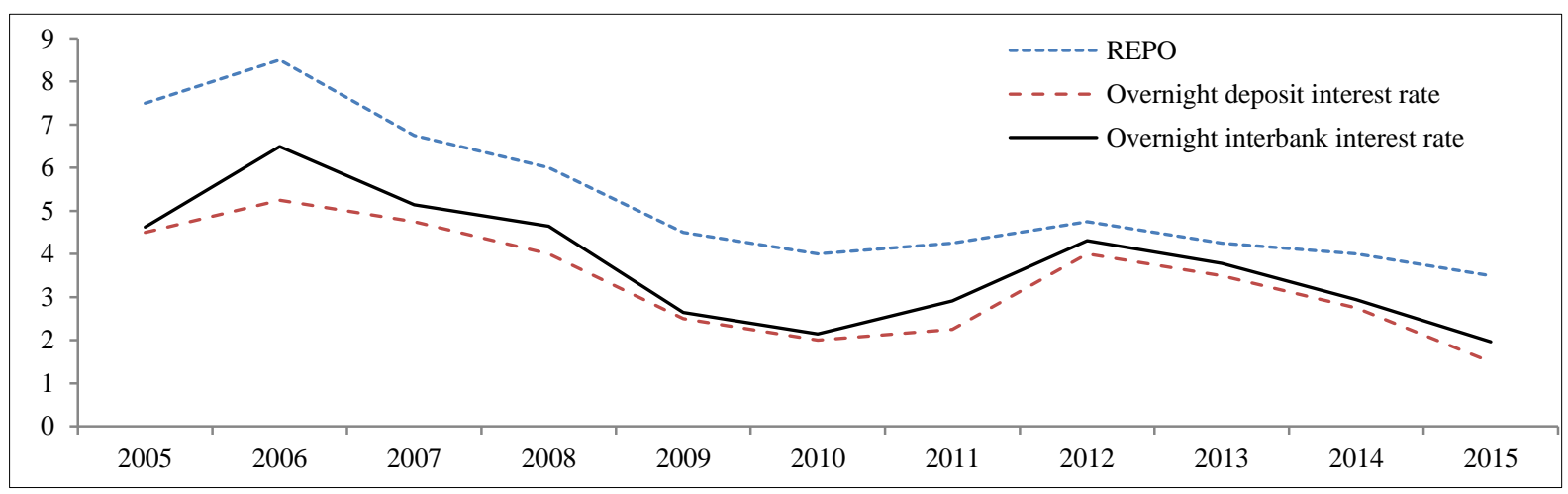

Figure 2. Overnight interbank interest rate, deposit interest rate and REPOs (2005-2015)

\subsubsection{CBJ Main Rate}

In the beginning of 2015, CBJ adopted this price as a main interest rate for managing the monetary policy. The CBJ main rate was decided to range between $2.5 \%$ and $2.75 \%$ (expressed in terms of REPOs for one week). This action aims to give clear signals about the stance of monetary policy and orientation about the domestic and international economic monetary and economic conditions.

\subsubsection{Certificates of Deposit}

To develop liquidity management tools to enhance the ability of banks to manage their liquidity efficiently and effectively, the Central Bank issued certificates of deposit with specific maturities and sizes in 2015 for the first time since 2008. This aims to attract part of the liquidity of banks through auctions within the range of pricing determined by the $\mathrm{CBJ}$ in accordance with the terms of this tool.

It is worth mentioning in this regard that even though interbank lending rate is not a monetary policy tool, it is included in this study due to its importance as being targeted indirectly by monetary policy.

\section{Jordan Economy Developments During the Period (2005-2015)}

Table 3 and Figure 3 include some macroeconomic indicators for Jordan during the period (2005-2015), when the national economy suffered severe shocks. The study period can be divided into three phases, as follows:

\section{5.l First Phase (2005-2007): High Growth-Moderate Inflation}

This period extends from 2005 to 2007. Before the global financial crisis, economic growth achieved high rates averaging $8.1 \%$. Whereas average inflation rate reached $4.8 \%$ and the current account deficit averaged $15.4 \%$ of GDP, and the average public debt reached $76.4 \%$ of GDP in the same period. Finally, the average unemployment 
reached high rates that amounted $14.0 \%$.

\subsection{Second Phase (2008-2011) Low Growth - High Inflation}

During this period, the global financial crisis occurred and its consequences remained for several years. This crisis has overshadowed the national economy, and the GDP growth rate declined in this period significantly compared to the first phase, where the growth rate of GDP reached $4.4 \%$ on average, while the average inflation rate was $7.7 \%$; With regard to unemployment rates, it had achieved an average $12.8 \%$. Although the national economy was affected the global financial crisis, the average total debt amounted to $71.9 \%$ of GDP (less than the previous period (2005-2007)), as the average current account deficit reached 8\% of GDP. Which is a clear decline compared to the previous period.

\subsection{Third Phase (2011-2015) Low Growth - Low Inflation}

The real economic growth during this period has been relatively modest since the beginning of the year 2011 compared to average real growth during previous periods. The continuing negative impact of the global financial crisis, the crisis in the European region and the consequences of the crisis in Iraq and Syria led significantly to economic recession as evident by the decline in growth rates until the end of 2013. The average GDP growth rate was approximately $2.7 \%$. Whereas the average inflation rate achieved a relatively low rate of $3.1 \%$ compared to its counterpart in the previous periods that reached $4.8 \%$ and $7.7 \%$ on average, respectively. Public debt averaged $83.3 \%$ of GDP during this period. While the average current account deficit approximated $10.4 \%$ of GDP. Perhaps the most prominent development during this period was the sharp increase in the population, as the number of Syrian refugees reached about 622.5 thousand refugees at the end of 2014 (about $96 \%$ of the total refugees in Jordan). Inevitably, this increase put a huge pressure on the Jordanian economy in various fields, especially in the fields of security, education, health. Besides increasing unemployment rate among Jordanians and, hence, adversely affected wage levels (Annual Report, Different years).

Table 3. Some macroeconomic indicators for Jordan (2005-2015)

\begin{tabular}{ccccccc}
\hline Year & $\begin{array}{c}\text { Current Account } \\
\text { (\% of GDP) }\end{array}$ & $\begin{array}{c}\text { Public Debt } \\
\text { (\% of GDP) }\end{array}$ & $\begin{array}{c}\text { Population } \\
\text { (count, millions) }\end{array}$ & $\begin{array}{c}\text { Unemployment } \\
\text { (\% of labor force) }\end{array}$ & $\begin{array}{c}\text { Inflation Rate } \\
\text { (period average, \%) }\end{array}$ & GDP Growth (\%) \\
\hline 2005 & -18.0 & 82.0 & 5.5 & 14.8 & 3.5 & 8.1 \\
2006 & -11.5 & 76.3 & 5.6 & 14.0 & 6.3 & 8.1 \\
2007 & -16.8 & 70.8 & 5.7 & 13.1 & 4.7 & 8.2 \\
2008 & -9.4 & 65.4 & 5.9 & 12.7 & 14.0 & 7.2 \\
2009 & -5.2 & 67.8 & 6.0 & 12.9 & -0.7 & 5.5 \\
2010 & -7.1 & 71.4 & 6.1 & 12.5 & 4.8 & 2.3 \\
2011 & -10.3 & 82.7 & 6.2 & 12.9 & 4.2 & 2.6 \\
2012 & -15.2 & 87.0 & 6.4 & 12.2 & 4.5 & 2.7 \\
2013 & -10.3 & 80.1 & 6.5 & 12.6 & 4.8 & 2.8 \\
2014 & -7.3 & 80.8 & 6.7 & 11.8 & 2.9 & 3.1 \\
2015 & -9.0 & 85.8 & 9.5 & 11.6 & $0.9-$ & 2.4 \\
\hline
\end{tabular}

Source: (Central Bank of Jordan, Statistical Database, 2017).

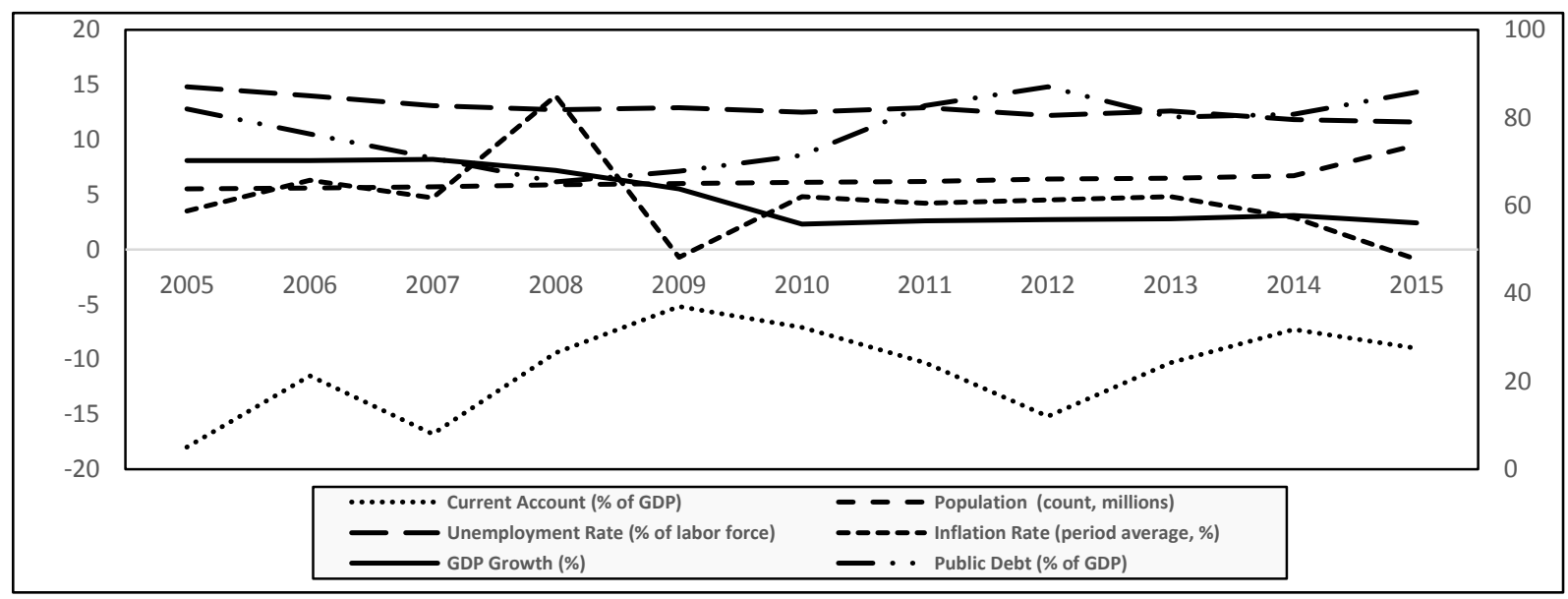

Figure 3. Some macroeconomic indicators for Jordan (2005-2015) 


\section{Research Methodology and Econometric Model}

If series levels are non-stationary then estimated regressions involving the levels cannot be trusted (spurious regressions). Differencing the series to make them stationary is one solution, but at the cost of ignoring possibly important (so called "long run") relationships between the levels.

A better solution is to test whether the levels regressions are trustworthy (a situation called "cointegration".) The usual approach is to use Johansen's method for testing whether or not cointegration exists. If the answer is "yes" then a vector error correction model (VECM), which combines levels and differences, can be estimated instead of a VAR in levels. If the answer is "no" then you are stuck with a VAR in differences.

This study will use the VECM to measure the impact of monetary policy on economic growth in Jordan. This examines the linkage between short-term and long-term changes in the study variables during the adjustment process. Therefore, in order to reach to long-term balance, this model can be applied for small samples. According to Greene (2007), cointegration relationship is required (by Johansen method) before applying this model (Greene, 2018).

Error correction method requires a mixture of information at levels and differences in the same equation, because the time series that is converted from nonstationary series to stationary series will lose important information on relationships between time series at the long term, the cointegration term is called Term Error Correction (TEC). The TEC relates to the fact that last periods` deviation from a long run equilibrium, the error, influences its short run dynamics. Thus, ECMs directly estimate the speed at which a dependent variable returns to equilibrium after a change in other variables.

Using VECM in models targeting exploring the term relationships is a common practice in growth studies (e.g. (Kularatne, 2002), (Sun, Ford, \& Dickinson, 2010), (Pradhan \& Bagchi, 2013), (De Mello \& Pisu, 2010), (Mahadevan \& Asafu-Adjaye, 2007)).

In light of the results of cointegration test, the long-run relationship will be tested by using VECM. This study uses the following model:

$$
G D P_{t}=\beta_{0}+\beta_{1} D I S C O U N T_{t}+\beta_{2} I N T E R_{t}+\beta_{3} R E Q R E S_{t}+\beta_{4} M 1_{t}+\epsilon_{t}
$$

Where:

$\beta s$ : Model parameters. t: Time series in years. $\epsilon_{t}$ : Random error. The model variables are shown in Table 3.

Table 3. Variables used in VECM

\begin{tabular}{ll}
\hline Variables & \\
\hline GDP & GDP Growth \\
DISCOUNT & Rediscount Rate \\
INTER & Overnight Weighted Average Interest Rates on Interbank Loans \\
REQRES & Required Reserved Ratio \\
M1 & The Growth of Money Supply M1 \\
\hline
\end{tabular}

The time series include quarterly data covering the period 2005-2015.

\subsection{Stationarity of the Time Series}

Before analyzing the results of the econometric model, the stationarity of time series must be tested to examine the presence of unit root problem in any of the model variables using ADF and PP test. As shown in

Table 4, all variable became stationary when testing the first difference of the variables, except M1, it was stationary at level.

Table 4. Stationarity testing using ADF and PP tests

\begin{tabular}{|c|c|c|c|c|c|c|}
\hline \multirow[t]{3}{*}{ Variable } & \multicolumn{6}{|c|}{ ADF Test } \\
\hline & \multicolumn{3}{|c|}{ Level } & \multicolumn{3}{|c|}{ First Difference } \\
\hline & $\mathrm{C}$ & $\mathrm{C}+\mathrm{T}$ & None & $\mathrm{C}$ & $\mathrm{C}+\mathrm{T}$ & None \\
\hline RGDP & -1.02 & -1.55 & -1.53 & $-5.94 * * *$ & $-5.87 * * *$ & $-5.80 * * *$ \\
\hline DISCOUNT & -0.66 & $-3.44^{*}$ & -0.36 & $-3.57 * *$ & $-3.69 * *$ & $-3.60 * * *$ \\
\hline INTER & -1.14 & -2.44 & -0.60 & $-6.97 * * *$ & $-7.10 * * *$ & $-7.03 * * *$ \\
\hline REQRES & -2.24 & -3.08 & -0.53 & $-7.96^{* * *}$ & $-7.86 * * *$ & $-8.03 * * *$ \\
\hline M1 & $-7.09 * * *$ & $-7.19 * * *$ & $-2.09 * *$ & $-11.80 * * *$ & $-11.72 * * *$ & $-11.85^{* * *}$ \\
\hline
\end{tabular}




\begin{tabular}{|c|c|c|c|c|c|c|}
\hline \multirow[b]{2}{*}{ RGDP } & \multicolumn{6}{|c|}{ PP Test } \\
\hline & -1.92 & -2.98 & $-2.13 * *$ & $-8.42 * * *$ & $-11.37 * * *$ & $-6.46 * * *$ \\
\hline DISCOUNT & -1.35 & -3.19 & -0.43 & $-3.47 * *$ & $-3.69 * *$ & $-3.52 * * *$ \\
\hline INTER & -1.39 & -2.63 & -0.63 & $-6.95 * * *$ & $-7.08 * * *$ & $-7.00 * * *$ \\
\hline REQRES & -2.13 & -3.08 & -1.14 & $-10.19 * * *$ & $-10.02 * * *$ & $-9.64 * * *$ \\
\hline M1 & $-6.91 * * *$ & $-10.22 * * *$ & $-4.65 * * *$ & $-15.81 * * *$ & $-16.36 * * *$ & $-15.37 * * *$ \\
\hline
\end{tabular}

Significant at $1 \% * * *, 5 \% * *$ or $10 \% *$.

\subsection{Cointegration Test}

To move forward using the VECM model, we must verify the existence of cointegration among nonstationary variables using Johansson test. If the cointegration among variables exists, then we can predict a long-term relationship. According to Johansson test, the null hypothesis include $\mathrm{r}$ or less cointegration relationships among variables, also we can test the speed of adjustment coefficient that provides a direct measure of the differentials in the adjustment processes. There are two types of Johansen test, either with trace or with eigenvalue. Table 5 shows the results of those tests, as noted by Trace Test, there is at least one long-term relationship among variables while Maximum Eigenvalue test shows the existence of two long-term relationship at least among variables. Thus, we can use the VECM model.

Table 5. Trace and maximum eigenvalue cointegration testing among nonstationary variables

\begin{tabular}{lcccc}
\hline & \multicolumn{3}{c}{ Unrestricted Cointegration Rank Test (Trace) } & \\
\hline Null Hypothesis & Eigenvalue & Trace Statistic & 5\% Critical Value & Prob. \\
\cline { 2 - 4 } None * & 0.683037 & 75.74489 & 47.85613 & 0.0000 \\
At least 1 & 0.397974 & 27.48818 & 29.79707 & 0.0902 \\
At least 2 & 0.112074 & 6.175111 & 15.49471 & 0.6748 \\
At least 3 & 0.027767 & 1.182701 & 3.841466 & 0.2768 \\
\hline & Unrestricted Cointegration Rank Test (Maximum Eigenvalue) & Prob. \\
\hline Null Hypothesis & Eigenvalue & Max-Eigen Statistic & 5\% Critical Value & 0.0000 \\
None * & 0.683037 & 48.25671 & 27.58434 & 0.0472 \\
At least 1 & 0.397974 & 21.31307 & 21.13162 & 0.7428 \\
At least 2 & 0.112074 & 4.992410 & 14.26460 & 0.2768 \\
At least 3 & 0.027767 & 1.182701 & 3.841466 & \\
\hline
\end{tabular}

Regarding the calculation of the optimal number of lags (Lag Length Selection),

Table 6, shows that the optimal number of lags using Akaike Information Criterion (AIC) and Hannan-Quinn Criterion (HQ) tests is five lags. However, when using the VECM model, one lag must be omitted. Therefore, the VECM model in this study will use four lags. It should be noted that choosing the number of lags depends on the frequency of the data. Usually a small number of lags is used for the annual data, and the largest number of lags is used for daily data, for example.

Table 6. Lag length selection for VECM using AIC and HQ tests

\begin{tabular}{ccc}
\hline Lag & AIC & HQ \\
\hline 0 & -31.6028 & -31.5263 \\
1 & -35.4199 & -34.9608 \\
2 & -36.4212 & -35.5795 \\
3 & -36.7030 & -35.4787 \\
4 & -37.3480 & -35.7410 \\
5 & -40.4991 & -38.5095 \\
\hline
\end{tabular}

\subsection{Estimating the VECM Model}

Table 7 shows the Statistical Results of the Estimated Econometric VECM Model for economic growth in Jordan, where a table shows the short and long-term elasticities and the Term Error Correction.

It also shows that the Term Error Correction is significantly negative, so that measures the speed of adjustment of imbalances in the short term to long term balance. This term contributes to explaining changes in economic 
growth, so 53\% of economic growth imbalances in the short term will be adjusted and corrected within two quarters (less than half a year).

The results indicate the existence of an inverse long and short-term relationship between Rediscount rate and the growth of GDP, the elasticity of the long-term relationship is about 1.75. Thus, the decline in the price of Re-Discount rate by $10 \%$ (for example) will lead to a rise in economic growth by $17.5 \%$. Furthermore, the results show the existence of a positive long and short relationship between overnight interbank rate and the growth of GDP, the elasticity of the long-term relationship about 0.70 . Thus, the increase in the overnight interbank rate by $10 \%$ will lead to a rise in economic growth by $7 \%$

With regard to the Required Reserved Ratio, the results shows that there is a long and short term relationship between this instrument and the growth of GDP, the elasticity of the long term relationship about 0.06 . Therefore, the increase in the Required Reserved Ratio by $10 \%$ will lead to a rise in economic growth by $0.6 \%$.

Finally, the results indicates the existence of a positive both long-term and short term relationship between the money supply growth (M1) and economic growth (GDP), the elasticity of the long-term relationship was about 0.03 . This means that an increase in the growth of money supply by $10.0 \%$ will lead to a rise in economic growth by $0.3 \%$.

\subsection{Stability Test}

Finally, the study has examined the stability of the long-term parameters together with the short-term movements for the model. For test, we relied on cumulative sum (CUSUM) and cumulative sum squares (CUSUMSQ) tests proposed by Borensztein et al. (1998). These tests show any structural change in the data, in addition to clarifying stability and harmony between the long term and short-term parameters. We can verify the existence of structural stability for the estimated parameters if the plot of both tests CUSUM and CUSUM of Squares stay within the critical 5\% level bounds (Borensztein, De Gregorio, \& Lee, 1998).

From Figure 4, it can be seen that the plot of CUSUM stays within the critical bounds, thus we can confirm the long-term relationships among variables, so the coefficient is stable. Figure 5 shows that CUSUMSQ exceeds the critical 5\% bounds during the period (2009-2011). This can be explained by the Jordanian economy suffering from several severe shocks during this period, most notably from the repercussions of the global financial crisis that heavily the Jordanian economy substantially during the period 2009-2011. In addition, Jordan has been affected since the beginning of 2011 by other shocks that have adversely affected the national economy, mainly political and economic conditions in the Middle East and their repercussions.

Furthermore, the National Electricity Company losses, hosting refugees and the increasing in the budget deficits have formed a pressure and burden on Jordan's economy. In addition, the decline in the national exports at the beginning of 2011, especially to and via the neighboring countries was due to the closure of border with Syria and Iraq, as the closing of borders with Syria and Iraq adversely affected Jordan's external trade with these two countries (Financial Stability Report, Different years).

Table 7. Statistical results of the estimated VECM model for economic growth in Jordan

\begin{tabular}{|c|c|c|c|}
\hline Variable & Coefficient & Standard Error & t-Statistics \\
\hline \multicolumn{4}{|c|}{ Long-Term } \\
\hline DISCOUNT(-1) & 3.0283 & 0.1997 & 15.1650 \\
\hline INTER(-1) & -1.3241 & 0.1426 & -9.2831 \\
\hline REQRES(-1) & 0.1060 & 0.2162 & 0.4904 \\
\hline M1(-1) & -0.0603 & 0.7593 & -0.7593 \\
\hline \multicolumn{4}{|c|}{ Short-Term } \\
\hline CoinEq1 & -0.5270 & 0.2498 & -2.0191 \\
\hline $\mathrm{D}(\mathrm{GDP}(-1))$ & -0.5174 & 0.2563 & 1.4837 \\
\hline $\mathrm{D}(\mathrm{GDP}(-2))$ & 0.2089 & 0.2540 & 0.8227 \\
\hline $\mathrm{D}(\mathrm{GDP}(-3))$ & 0.0352 & 0.1269 & 0.2776 \\
\hline $\mathrm{D}(\mathrm{GDP}(-4))$ & -0.0129 & 0.1340 & -0.0962 \\
\hline D(DISCOUNT(-1)) & 0.0537 & 1.1289 & 0.0475 \\
\hline D(DISCOUNT(-2)) & 0.2150 & 0.6210 & 0.3462 \\
\hline D(DISCOUNT(-3)) & -0.4876 & 0.6474 & -0.7531 \\
\hline D(DISCOUNT(-4)) & -2.6211 & 0.5097 & -5.1421 \\
\hline D(INTER(-1)) & 0.2927 & 0.4791 & 0.6109 \\
\hline
\end{tabular}




\begin{tabular}{llll}
\hline D(INTER(-2)) & 0.2519 & 0.5401 & 0.4664 \\
D(INTER(-3)) & 0.4673 & 0.4627 & 1.0099 \\
D(INTER(-4)) & 1.4031 & 0.3231 & 4.3433 \\
D(REQRES(-1)) & 0.6052 & 0.4129 & 1.4657 \\
D(REQRES(-2)) & -0.9494 & 0.3188 & -2.9778 \\
D(REQRES(-3)) & -0.2972 & 0.3897 & -0.7628 \\
D(REQRES(-4)) & -0.7666 & 0.3589 & -2.1359 \\
D(M1(-1)) & -0.1855 & 0.0505 & -3.6777 \\
D(M2(-1)) & -0.1293 & 0.0585 & 2.2126 \\
D(M3(-1)) & -0.1633 & 0.0609 & -2.6820 \\
D(M4(-1)) & -0.1325 & 0.0530 & 2.4973 \\
C & -0.0006 & 0.0013 & -0.4421 \\
\hline R
\end{tabular}

$\mathrm{R}^{2}=0.90$, Adjusted $\mathrm{R}^{2}=0.77$, F-Stat. $=6.962928$.

Autocorrelation LM Test: LM-Stat. $=22.3321$, Prob. $=0.6165$

Normality Test: Jarque-Bera $=18.13588$, Prob. $=0.0527$

Based on the results listed in Table 7, VECM model can be derived as follows:

$\mathrm{D}(\mathrm{GDP})=-0.53 *[-\mathrm{GDP}(-1)+3.3 *$ DICOUNT(-1)-1.32*INTER(-1)+0.11*REQRES(-1)-0.06*M1(-1)-0.07]

$\mathrm{D}(\mathrm{GDP})=-0.53 * \mathrm{GDP}(-1)-1.75 * \operatorname{DISCOUNT}(-1)+0.70 * \operatorname{INTER}(-1)-0.06 * \operatorname{REQRES}(-1)+0.03 * \mathrm{M}(-1)+0.04$

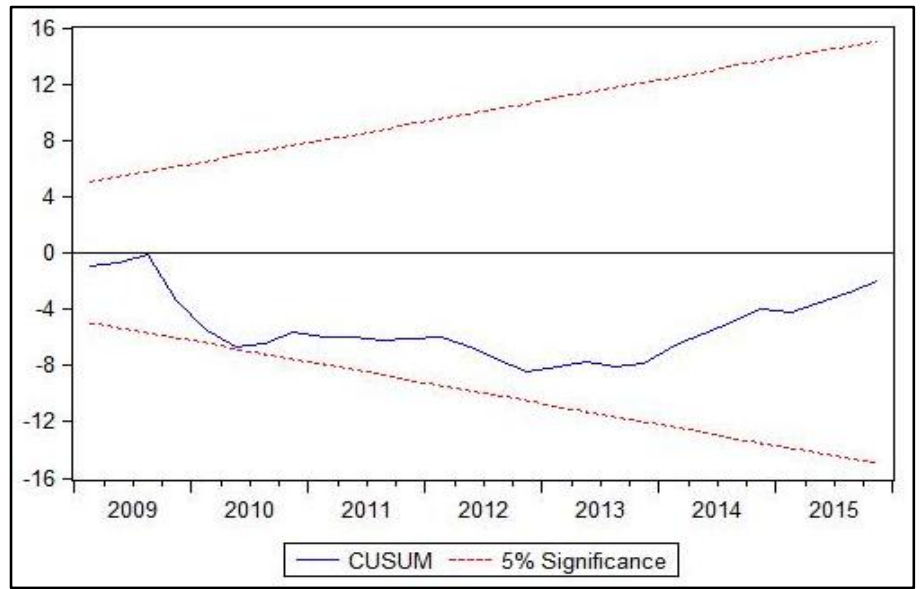

Figure 4. Plots of Residuals CUSUM

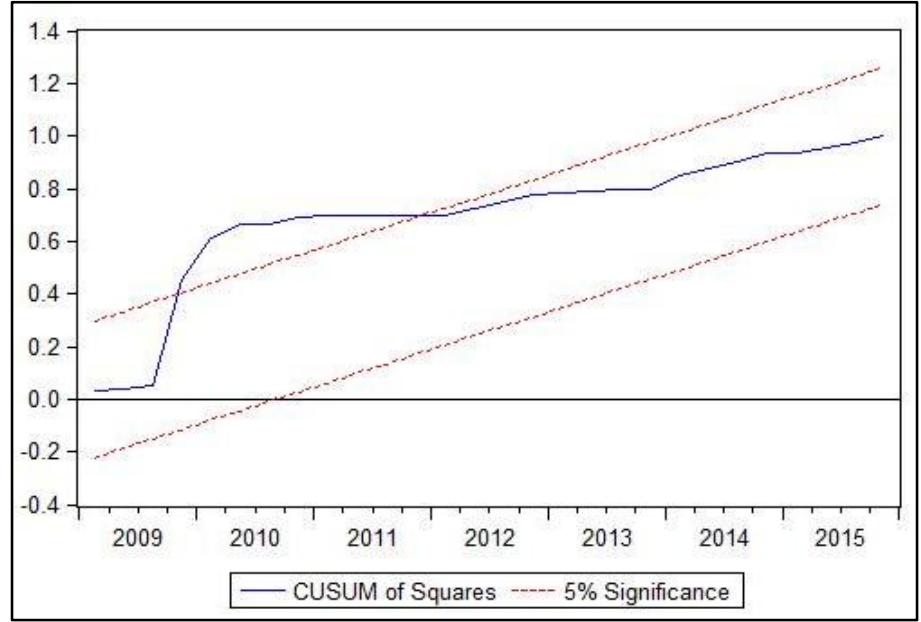

Figure 5. Plots of Residuals CUSUMSQ 


\section{Conclusions and Recommendations}

\subsection{Conclusions}

This study investigated the effect of monetary policy instruments on the performance of the Jordanian economy (GDP growth). Using quarterly data covering the period (2005-2015), an econometric model was examined using Model VECM model to measure the impact of monetary policy on economic growth. The results showed the existence of positive long-term and short-term effect of monetary policy tools that included required reserve ratio, money supply (M1) and overnight interbank rates, on economic growth in Jordan. The results showed also an existence of inverse relationship between rediscount rate and economic growth in Jordan over both long and short terms.

\subsection{Recommendations}

The literature support the results of this paper, the interest rate mechanism is a "strong" mechanism as supported by the empirical literature (Taylor, 1995). However, generally, Papadamou, Sidiropoulos, and Spyromitros (2015) claim transparency plays an essential role in the transmission of monetary policy. They tested this preposition on emerging market economy countries, of which Jordan is one (Papadamou, Sidiropoulos, \& Spyromitros, 2015).

Besides, this study came out with the following recommendations:

- It is important for the CBJ to continue using the appropriate monetary policy tools to support Jordan's economic growth taking into account economic and political conditions surrounding the Middle East region.

- The study emphasizes the importance of the role of the Central Bank to stimulate the performance of the Jordanian economy. In addition to maintaining positive economic growth rates to enhance financial, monetary and economic stability and to provide an attractive investment environment.

- It is important to coordinate between monetary and fiscal policies in support of Jordan's economy.

\section{Acknowledgements}

Opinions in the paper do not necessarily reflect those of the Central Bank of Jordan. All mistake are ours.

\section{References}

Abdul-Khaliq, S., Soufan, T., \& Abu Shihab, R. (2013). Intensive Economic Growth in Jordan during 1978-2010. International Journal of Business and Management, 8(12), 143-154. https://doi.org/10.5539/ijbm.v8n12p143

Algahtani, G. (2015). Impact of Rising Interest Rate on Saudi Economy. Saudi Arabian Monetary Authority (SAMA) Working Paper, WP/15/4.

Annual Report. (Different years). Central Bank of Jordan.

Assaf, A. (2014). The Effect of Macroeconomic Variables on Jordan's Economic Growth. European Journal of Social Sciences, 101-111. Retrieved October 17, 2017, from https://www.researchgate.net/publication/283496848_The_Effect_of_Macroeconomic_Variables_on_Jorda n's_Economic_Growth

Balogun, D. (2007). Monetary policy and economic performance of West African Monetary Zone Countries. Retrieved October 14, 2017 from http://mpra.ub.uni-muenchen.de/4308/

Basu, P. (2001). Reserve ratio, seigniorage and growth. Journal of Macroeconomics, 23(3), 397-416. https://doi.org/10.1016/S0164-0704(01)00170-7

Borensztein, E., De Gregorio, J., \& Lee, J. W. (1998). How does foreign direct investment affect economic $\begin{array}{llll}\text { growth? Journal of International } & \text { Economics, }\end{array}$ https://doi.org/10.1016/S0022-1996(97)00033-0

Central Bank of Jordan. (2017). Monthly Statistical Bulletin.

Central Bank of Jordan. (2017). Statistical Database. Retrieved from http://www.cbj.gov.jo/: http://www.cbj.gov.jo/Pages/viewpage.aspx?pageID=40

Chari, V., Jones, L., \& Manuelli, R. (1995). The growth effects of monetary policy. 19(4), p. 18. Retrieved October 2017

from https://pdfs.semanticscholar.org/bc64/9b1d2ab5af9cb5b88065c7904d62aa5c91cb.pdf

De Mello, L., \& Pisu, M. (2010, February). The bank lending channel of monetary transmission in Brazil: A VECM approach. The Quarterly Review of Economics and Finance, 50(1), 50-60. 
https://doi.org/10.1016/j.qref.2009.09.006

Easterly, W., King, R., Levine, R., \& Rebelo, S. (1994, March). Policy, technology adoption and growth. NBER Working Paper. https://doi.org/10.3386/w4681

Einsig, P. (1954). How money is managed: the ends and means of monetary policy. Penguin Books.

Fasanya, I., \& Onakoya, A. (2013). Does monetary policy influence economic growth in Nigeria? Asian Economic and Financial Review, 3(5), 635-646.

Financial Stability Report. (Different years). Central Bank of Jordan.

Friedman, M., \& Schwartz, A. (1973). Money and Banking. A Dision of Penguin Books, 106-116.

Glahe, F. (1977). Macroeconomics theory and policy (2nd ed., p. 289). Harcourt Brace Jovanovich, Inc.

Greene, W. (2018). Econometric Analysis. London, England: Pearson, PLC.

Kularatne, C. (2002, March). An Examination of the Impact of Financial Deepening on Long-Run Economic Growth:An Application of a VECM Structure to a Middle-Income Country Context. South African Journal of Economics, 70(4), 300-319. https://doi.org/10.1111/j.1813-6982.2002.tb01185.x

Lacker, J. (2014, February 24). Can Monetary Policy Affect Economic Growth? Retrieved October 14, 2017 from https://www.richmondfed.org/-/media/richmondfedorg/press_room/speeches/president_jeff_lacker/2016/pd f/lacker_speech_20160224.pdf

Levine, R., \& Renelt, D. (1992). A sensitivity analysis of cross-country growth regressions. American Economic Review, 82(4), 942-963.

Mahadevan, R., \& Asafu-Adjaye, J. (2007, April). Energy consumption, economic growth and prices: A reassessment using panel VECM for developed and developing countries. Energy Policy, 35(4), 2481-2490. https://doi.org/10.1016/j.enpol.2006.08.019

Mishkin, F. (1996). The Channels of Monetary Transmission: Lessons for Monetary Policy. NBER Working Paper No. 5464, 1-26. https://doi.org/10.3386/w5464

Nouri, M., \& Samimi, A. (2011). The Impact of Monetary Policy on Economic Growth in Iran. Middle-East Journal of Scientific Research, 740-743.

Papadamou, S., Sidiropoulos, M., \& Spyromitros, E. (2015, August). Central bank transparency and the interest rate channel: Evidence from emerging economies. Economic Modeling, 48, 167-174. https://doi.org/10.1016/j.econmod.2014.10.016

Patat, J. (1987). Monnaie, Institution Financières et Politiques monétaires. Economica.

Pradhan, R., \& Bagchi, T. (2013, February). Effect of transportation infrastructure on economic growth in India: The VECM approach. Research in Transportation Economics, 38(1), 139-148. https://doi.org/10.1016/j.retrec.2012.05.008

Precious, C., \& Palesa, M. K. (2014). Impact of Monetary Policy on Economic Growth: A Case Study of South Africa. Mediterranean Journal of Social Sciences, 6(15). https://doi.org/10.5901/mjss.2014.v5n15p76

Sun, L., Ford, J., \& Dickinson, D. (2010, March). Bank loans and the effects of monetary policy in China: VAR/VECM approach. China Economic Review, 21(1), 65-97. https://doi.org/10.1016/j.chieco.2009.11.002

Taylor, J. (1995). The Monetary Transmission Mechanism: An Empirical Framework. Journal of Economic Perspectives, 9(4). https://doi.org/10.1257/jep.9.4.11

\section{Copyrights}

Copyright for this article is retained by the author(s), with first publication rights granted to the journal.

This is an open-access article distributed under the terms and conditions of the Creative Commons Attribution license (http://creativecommons.org/licenses/by/4.0/). 